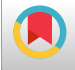

\title{
Response Surface Design for Removal of Lead by Different Lactic Acid Bacteria
}

\author{
Leila Goudarzi (iD ${ }^{1}$, Rouha Kasra Kermanshahi (iD ${ }^{1,}{ }^{*}$ and Gholamreza Jahed Khaniki (iD) ${ }^{2}$ \\ ${ }^{1}$ Department of Microbiology, Faculty of Science, Alzahra University, Tehran, Iran \\ ${ }^{2}$ Department of Environmental Health Engineering, School of Public Health, Tehran University of Medical Sciences, Tehran, Iran \\ "Corresponding author: Department of Microbiology, Faculty of Science, Alzahra University, Tehran, Iran. Tel: +98-9131150779, Email: rkasra@yahoo.com
}

Received 2020 January 15; Revised 2020 May 09; Accepted 2020 May 20.

\begin{abstract}
Background: Toxic heavy metals, such as lead, are widely used in industry and may cause serious health problems and ecological hazards for living organisms.

Objectives: The current study aimed to investigate the removal efficiency of lead by Lactobacillus strains using a methodological approach.

Methods: After selecting the bacteria with the maximum metals removal ability, experiments were conducted according to (i) the Plackett-Burman design (Minitab18 program) to screen several significant process factors and (ii) Central Composite Design (DesignExpert 11.1.2.0 program) to find out the optimum process conditions for the maximum capacity of metal removal efficiency.

Results: The optimum pH, metal, and bacterial concentration were $6.76,391 \mathrm{mg} . \mathrm{L}^{-1}$, and $4.60 \mathrm{~g} . \mathrm{L}^{-1}$ for lead removal ability of $L$. acidophilus ATCC4356. A quadratic model was developed to correlate the variables with removal efficiency. According to the results, this model was not statistically significant $(\mathrm{P}>0.05)$.

Conclusions: The experimental removal efficiencies at the optimum condition for lead by L. acidophilus ATCC4356 (73.9\%) were consistent with the predicted values. Consequently, due to their appreciate efficiency and the lower cost of the lead removal ability, these two bacteria may be a candidate as good biosorbents. The results also confirmed that the Response Surface Methodology is an appropriate methodology for modeling of removal efficiency.
\end{abstract}

Keywords: Lead, Response Surface Methodology (RSM), Lactic Acid Bacteria

\section{Background}

Lead $(\mathrm{Pb})$ is one of the most abundant toxic heavy metals which tends to accumulate in living organisms and causes a variety of adverse health effects for humans (1-4). In humans, exposure to lead can cause renal, skeletal, hepatic, pulmonary, neurologic and hematological, cardiovascular, reproductive, and cardiovascular dysfunction (5-8).

In recent years, due to the expansion of industrial activities, contamination in the environment and the food chain has increased (9); Therefore, the digestive system of the body is prone to lead contamination (10). Since pollution caused by heavy metal has severe health consequences, their removal is of crucial importance. Recent studies were mainly focused on discovering new and cheap methods of metal ions removal (11). Among the conventional treatment methods, 'adsorption' has attracted considerable attention in recent years, mainly because of its metal binding capacities and cost-benefits (4). Since the dynamic characteristics of the adsorption process are com- plex, having the optimum working condition is essential to achieve optimum pollution removal efficiency. Adsorbents may be of mineral, organic, or biological origin by using live or dead microbial organisms (2). According to the literature, lactic acid bacteria (LAB) have efficient removal ability among the microbial organisms (5,12-14). Recently, several studies have reported that LAB, and more particularly lactobacilli, which are generally recognized as safe probiotics, could identify heavy metals in food and water and perhaps gastrointestinal tract as well, due to their heavy metals binding ability $(15,16)$. Therefore, the applications of LAB in the food industry and probiotics products have expanded recently $(6,12)$. The ability to bind lead is reported for several probiotic and food-grade Lactobacillus strains $(12,17,18)$.

\section{Objectives}

Several studies showed that culture conditions substantially affect the removal ability of heavy metals by mi- 
croorganisms $(2,5,7,18)$. However, the effects of culture conditions on lactobacilli removal efficiency against lead are less investigated (8). Several optimization techniques are developed to achieve this goal (7). Classical and conventional methods cannot depict all factor combinations which can affect the experiments. Meanwhile, determining the optimum level using these methods requires a lot of time. The current study has used the Response Surface Method (RSM), which is a mathematical and statistical technique to investigate the association between a group of controlled experimental factors and measures' responses according to one or more criteria $(10,19-21)$. The RSM is one of the most widely used methods as it develops, improves, and optimizes the processes, particularly in the presence of complex interactions (22). The greatest advantage of the RSM with CCD or Box-Behnken design is decreasing the number of experimental trials required to interpret multiple parameters (23). Therefore, the current study aimed to investigate how the cultural and bacterial conditions can affect lead removal ability of examined lactobacillus strains and to select the optimum conditions for removal activity.

\section{Methods}

\subsection{Heavy Metals}

Lead ( 2 mg.mL $\left.{ }^{-1}\right)$ stock solutions were prepared from $\mathrm{Pb}$ $\left(\mathrm{No}_{3}\right)_{2}$ (Sigma-Aldrich), respectively, in Milli-Q water. The stock solutions were sterilized by passing through a 0.22 $\mu \mathrm{m}$ syringe filter and then stored at $4^{\circ} \mathrm{C}$ until use.

\subsection{Bacterial Strains}

In the current study, the five Lactobacillus strains were used, that all of which were purchased from the Iranian Research Organization for Science and Technology (IROST): Lactobacillus acidophilus ATCC4356, Lactobacillus Plantarum ATCC8014, Lactobacillus fermentum ATCC9338, Lactobacillus casei ATCC39392, and Lactobacillus rhamnosus ATCC7469. All strains were cultured in deMan, Rogosa, Sharpe (MRS) broth (Merck, Germany), under microaerophilic conditions at $37^{\circ} \mathrm{C}$.

\subsection{Determining Lead Removal Activities of Each Strain}

The lead removal activity of the five strains was analyzed according to the methodology proposed by Zhai and colleagues (5). Briefly, cultured biomass was centrifuged at $8000 \times \mathrm{g}$ (Centrifuge Sorvall. RC-5B) for 20 min after incubation of the strains. Then, cell pellets were washed two times, weighed and resuspended in ultrapure water containing $50 \mathrm{mg} . \mathrm{L}^{-1}$ lead to give a final bacterial concentration of $1 \mathrm{~g} \cdot \mathrm{L}^{-1}$ (wet weight). The $\mathrm{pH}$ of the suspension was adjusted to 6 by dilute $\mathrm{HNO}_{3}$ or $\mathrm{NaOH}$. After $1 \mathrm{~h}$ incubation at $37^{\circ} \mathrm{C}$, the suspension was centrifuged at $8000 \times \mathrm{g}$ for 20 min; a sample was taken from the supernatant for the analysis of residual lead concentration, which was measured by Inductively Coupled Plasma-optical emission spectrometry (ICP-MS). The lead removal activity (as a percentage) of the strains (bound by the bacteria) were expressed as follows:

Removal $(\%)=100 \% \times\left[\left(C_{0}-C_{1}\right) / C_{0}\right]$

where $\mathrm{C}_{0}\left(\mathrm{mg} . \mathrm{L}^{-1}\right)$ and $\mathrm{C}_{1}\left(\mathrm{mg} . \mathrm{L}^{-1}\right)$ are the initial and final metal ion concentrations in the solution, respectively (24). Strains with relatively high lead removal activity in the removal assay were selected for further optimization.

\subsection{Optimization Experiment}

The optimization experiment was performed in two steps. First, the important factors were selected, and then the optimum condition for lead removal by Lactobacillus strains was determined. The Plackett-Burman design (11) by the Minitab18 program was used for selecting the important factors. A 12 run Plackett-Burman design was applied to evaluate the important variables for six factors by two levels (the lower and higher levels of the factors were selected, respectively) (10). In the second step, the optimum condition for lead removal was done by RSM (9). The experiment was designed with 18 trials, according to the Central Composite Design (17). Each trial was performed in duplicates.

In the current study, different factors (live status, $\mathrm{pH}$, temperature, bacterial and metal concentration) affecting the process of biosorption, were optimized and controlled by using boiling water (live/dead bacteria), acid/base addition ( $\mathrm{pH})$, cooling jackets (temperature), and baffles/agitators (same level of bacterial and metal concentration).

\subsection{Statistical Analysis}

Data were analyzed using Design-Expert 11.1.2.0 program. Analysis of variance (ANOVA), probability values ( $P$ value), and three-dimensional curves of the response surfaces were used to investigate the interaction between variables and the response.

\section{Results}

\subsection{Lead Removal Activity of Lactobacillus strains}

The percentage of lead removed (bound by the bacteria) by each of the five Lactobacillus strains is shown in Table 1. Metals removal efficiencies varied from 30.5 to $53.9 \%$. Hence, L. acidophilus ATCC4356 was screened for further optimization, with the maximum percentage removal for lead $(53.9 \pm 0.01 \%)$. 


\begin{tabular}{lc}
\hline \multicolumn{2}{l}{ Table 1. Removal of Lead from MRS Broth by Lactobacillus Strains ${ }^{\mathrm{a}, \mathrm{b}}$} \\
\hline Lactobacillus Strains & \% Pb Removed \\
\hline L. acidophilus ATCC4356 & $53.9 \pm 0.013$ \\
L. plantarum ATCC8014 & $47.7 \pm 0.025$ \\
\hline L. rhamnosus ATCC7469 & $30.5 \pm 0.054$ \\
L.fermentum ATCC9338 & $44.2 \pm 0.04$ \\
\hline L. casei ATCC39392 & $33.3 \pm 0.02$ \\
\hline
\end{tabular}

${ }^{\mathrm{a}}$ The bacteria were incubated $24 \mathrm{~h}$ in MRS broth supplemented with $5 \mathrm{mg} \cdot \mathrm{L}^{-1} \mathrm{~Pb}$ ${ }^{b}$ Values are mean $\pm S D$ of three replicates.

\subsection{Plackett-Burman Design Analysis to Find Critical Factors for Response Values of Lead Removal}

Investigated factors, Plackett-Burman design, and the corresponding response measurements, which were randomized according to the run number, are shown in Table 2 .

ANOVA and Pareto charts were used to analyze the significance of the effects. Pareto chart examines how the factors significantly affect the response and help in comparing the relative importance of the effects (4). The interpretation of this chart demonstrates that $\mathrm{pH}$, biomass concentration (g. $\left.\mathrm{L}^{-1}\right)$, and concentration of metals (mg. $\mathrm{L}^{-1}$ ) were highly significant, and other factors were less significant (with a confidence interval of $<95 \%$ and $\mathrm{P}<0.05$ )) (Figures $1 \mathrm{~A}$ and $2 \mathrm{~A}$ ). Normal probability plot (Figures $1 \mathrm{~B}$ and 2B), residual versus order plot (Figures $1 C$ and $2 C$ ), and residual versus fitted plot (Figures 1D and 2D) showed the same insinuations; thus, the model fits the data well and follows a normal distribution in both strains.

4.3. Optimum Factors for Response Values of Metal Removal and Analysis for the Central Composite Design

Biomass concentration, $\mathrm{pH}$, and concentration of metals (lead) were left to be optimized after the PlackettBurman design. The screening was planned according to the principle of the central composite design, such that the $\mathrm{pH}(\mathrm{A})$, metal concentration (B, $\left.\mathrm{mg} \cdot \mathrm{L}^{-1}\right)$, and bacterial concentration $\left(C\right.$, g. $\left.\mathrm{L}^{-1}\right)$ were defined as independent values and lead removal ( $R$, percentage) was defined as the response value in the mathematical modeling for $L$. acidophilus ATCC4356. The range of independent experimental variables, coded variables, and the results of the experiment are shown in Table 3.

The results of the ANOVA are shown in Table 4. Statistical parameters such as $F$ value, $R^{2}$, adj. $R^{2}$, predicted $R^{2}$, and lack of fit were evaluated and compared with the experimental results for the reliability of the model. The analysis showed that the lack of fit was not significant $(\mathrm{P}>0.05)$ and two models were significant $(\mathrm{P}<0.05)$. The coefficient of determination $\left(\mathrm{R}^{2}\right)$ for lead removal was 0.94 (that is, the fitted models were adequate). According to the analyses, a quadratic model equation was developed. The results of the ANOVA are shown in Table 4 . The association between independent variables and response was drawn by second-order polynomial equations. Final equations were expressed as follows:

For coded factors:

$$
\begin{aligned}
R(\text { Pb removal })= & +53.7+7.41 A-0.36 B \\
& +3.20 C-9.28 A B+9.22 A C \\
& +9.76 B C-2.28 A^{2}
\end{aligned}
$$

For actual factors:

$$
\begin{aligned}
R(\text { Pb removal })= & +42.9+9.39 \mathrm{pH} \\
& +0.04 \text { Pb concentration } \\
& -26.2 \text { Bacterial Concentration } \\
& -0.03 p H * \text { Pb concentration } \\
& +3.03 p H * \text { Bacterial Concentration } \\
& +0.04 \mathrm{~Pb} \text { concentration } \\
& * \text { Bacterial Concentration }-0.52 \mathrm{pH}^{2}
\end{aligned}
$$

\subsection{Response Surface Modeling and Process Optimization}

The 3D plots of the response surface for the highest removal efficiency in an optimized condition are presented in Figure $2 \mathrm{~A}-\mathrm{C}$ for $\mathrm{R}$. Figure $2 \mathrm{~A}$ represents the combined effect of $\mathrm{pH}(\mathrm{A})$ and lead concentration (B). Both parameters affect the lead removal synergistically. By increasing each of the two independent variables, the removal efficiency increases. The effect of $\mathrm{pH}(\mathrm{A})$ and bacterial concentration $(C)$ on removal efficiency is shown in Figure 2B. The combined effect of $\mathrm{pH}(\mathrm{A})$ and bacterial concentration (C) affect the lead removal activity (Figure $2 \mathrm{~B}$ ) synergistically. The combined effect of lead concentration (B) and bacterial concentration $(C)$ on metal removal efficiency is shown in Figure 2C. As shown, by moving toward the maximum bacterial concentration and lower lead concentration at a constant $\mathrm{pH}$ (6.8), the removal values decrease dramatically.

\subsection{Verification}

This step aimed to verify the optimization capability of the models generated according to the results of the CCD. The maximum metal removal efficiencies of Lactobacillus strains were investigated when the optimal process variable (A, B, and C) were equal to $6.76,391 \mathrm{mg} . \mathrm{L}^{-1}$ and 4.65 g. $\mathrm{L}^{-1}$ for lead removal of L. acidophilus ATCC4356. The experimental and predicted removal efficiencies at the optimum condition were found as 73.960 and $75.710 \%$ for L. acidophilus ATCC4356, respectively (95\% PI low $=63.4$ and 95\% PI high =79.4) 


\begin{tabular}{|c|c|c|c|c|c|c|c|c|}
\hline \multirow{2}{*}{ Standard No. } & \multirow{2}{*}{ Run } & \multicolumn{6}{|c|}{ Factors } & \multirow{2}{*}{ Removal of Lead (\%) for L. acidophilus ATCC4356 } \\
\hline & & $\mathbf{A}$ & B & C & D & $\mathbf{E}$ & $\mathbf{F}$ & \\
\hline 7 & 1 & - & + & + & + & - & + & 68.9 \\
\hline 5 & 2 & + & + & - & + & + & - & 55.6 \\
\hline $\mathbf{1}$ & 3 & + & - & + & - & - & - & 55.7 \\
\hline 4 & 4 & + & - & + & + & - & + & 71.1 \\
\hline 3 & 5 & - & + & + & - & + & - & 54.0 \\
\hline 2 & 6 & + & + & - & + & - & - & 53.6 \\
\hline 12 & 7 & - & - & - & - & - & - & 52.9 \\
\hline 10 & 8 & + & - & - & - & + & + & 53.9 \\
\hline 8 & 9 & - & - & + & + & + & - & 62.4 \\
\hline 11 & 10 & - & + & - & - & - & + & 54.3 \\
\hline 9 & 11 & - & - & - & + & + & + & 57.1 \\
\hline 6 & 12 & + & + & + & - & + & + & 59.7 \\
\hline
\end{tabular}

Abbreviations: A, live status; B, time (hour); C, pH; D, bacterial concentration (g.L $\left.\mathrm{L}^{-1}\right)$; E, temperature $\left({ }^{\circ} \mathrm{C}\right) ; \mathrm{F}$, metal (lead) concentration (mg. $\left.\mathrm{L}^{-1}\right)$.

a - and + represent the low and high levels, respectively.

\section{A Pareto Chart of the Standardized Effects}

(Response is Pb Removal; $\alpha$ 0.05)

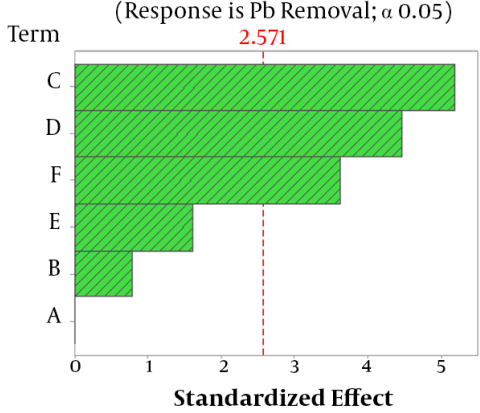

C

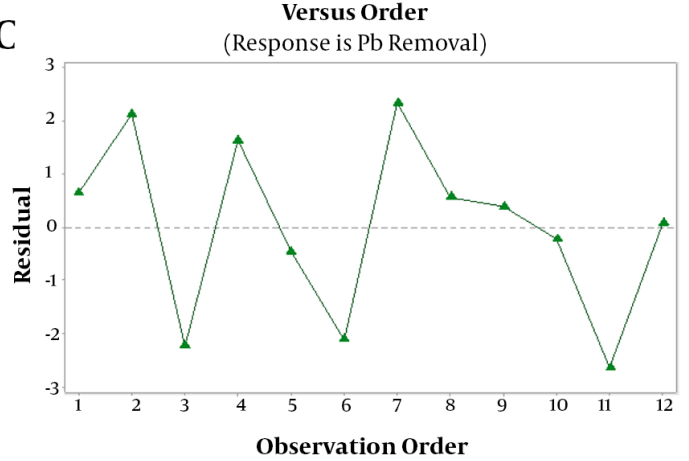

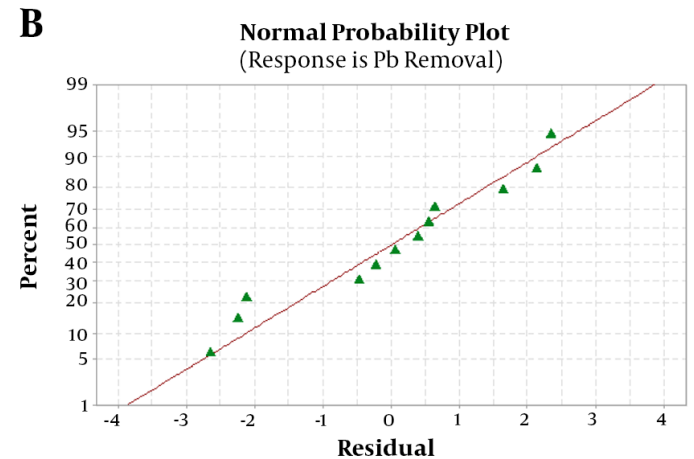

D

Versus Fits

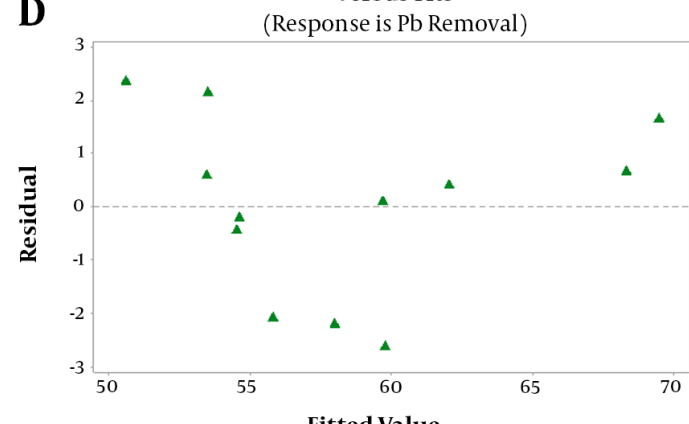

Fitted Value

Figure 1. A) Pareto chart, B) normal probability plot, C) residual versus order plot, and D) residual versus fitted plot for Plackett-Burman design (PBD) for lead removal of $L$. acidophilus ATCC4356. 
A

Design Expert $₫$ Software

Factor Coding: Actual

R1 (Pb Removal) (\%)

$34.7059=71.9601$

$\times 1=\mathrm{A}: \mathrm{pH}$

$\times 2=\mathrm{B}: \mathrm{pb}$ concentration

Actual Factor

C: Bactenal Concentration $=4.7$

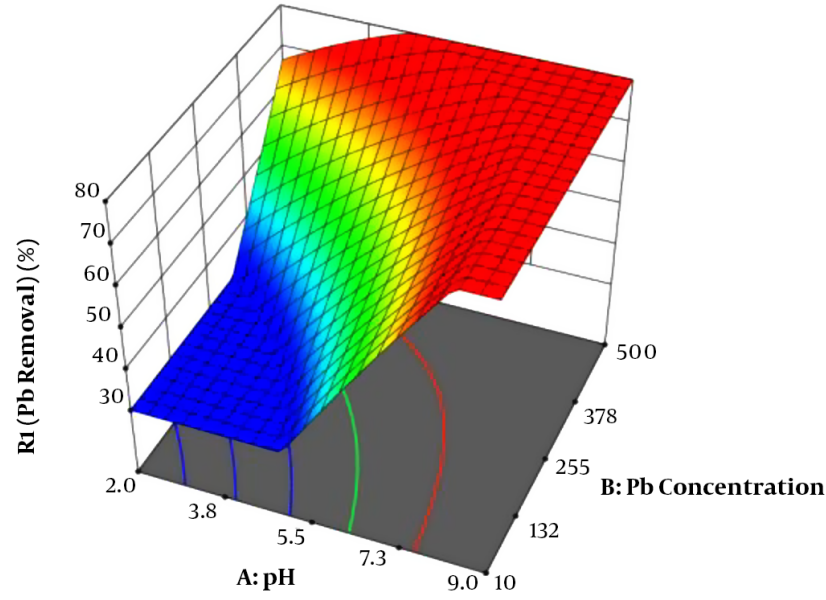

B

Design Expert Software

Factor Coding: Actual

R1 (Pb Removal) (\%)

$34.7059=71.9601$

$\times 1=\mathrm{A}: \mathrm{pH}$

$\times 2=\mathrm{C}:$ Bacterial Concentration

Actual Factor

$\mathrm{B}: \mathrm{Pb}$ Concentration $=391$

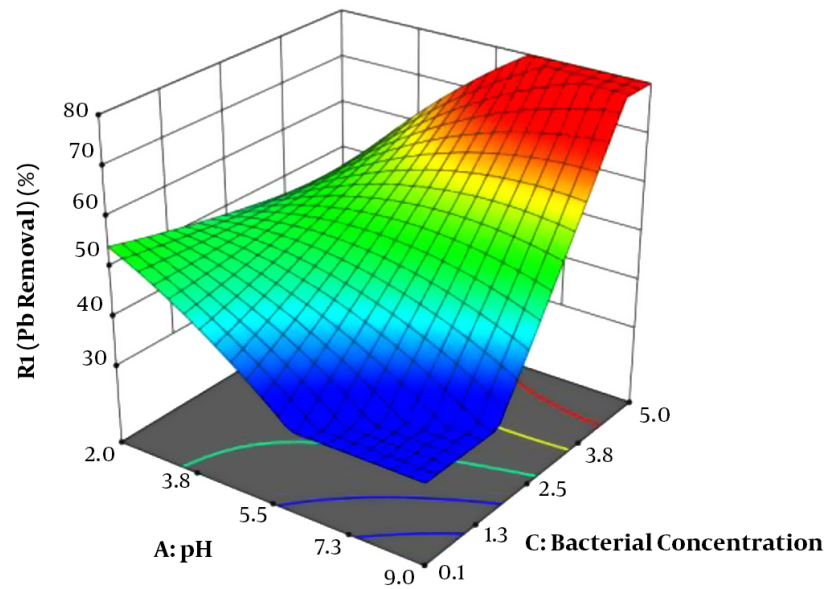

C

Design Expert * Software

Factor Coding: Actual

R1 (Pb Removal) (\%)

$34.7059 \approx 71.9601$

$\times 1=\mathrm{B}: \mathrm{Pb}$ Concentration

$\times 2=$ C: Bacterial Concentration

Actual Factor

$\mathrm{A}: \mathrm{pH}=6.8$

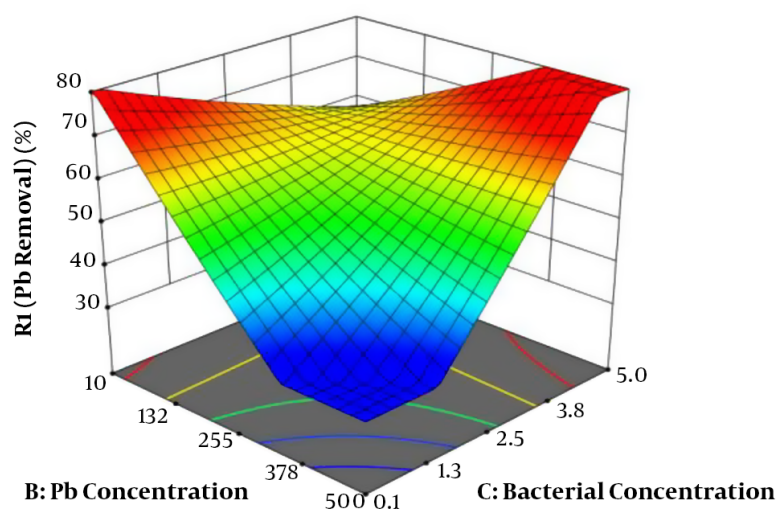

Figure 2. Fitted surface for the lead removal as: $\mathrm{A}) \mathrm{pH}(\mathrm{A})$ and $\mathrm{Pb}$ concentration $(\mathrm{B})$ (Bacterial concentration $=4.7), \mathrm{B}) \mathrm{pH}(\mathrm{A})$ and bacterial concentration $(\mathrm{B})(\mathrm{Pb}$ concentration $=$ $391), \mathrm{C}) \mathrm{Pb}$ concentration $(\mathrm{B})$ and bacterial concentration $(\mathrm{C})(\mathrm{pH}=6.8)$. 


\begin{tabular}{|c|c|c|c|c|}
\hline \multirow{3}{*}{ Run } & \multicolumn{3}{|c|}{ No. of Factors (-1 Level, + 1 Level) } & \multirow{3}{*}{$\begin{array}{c}\text { Response } \\
\mathbf{R} \\
\text { Lead Removal (\%) }\end{array}$} \\
\hline & $\mathbf{1}$ & 2 & 3 & \\
\hline & A: $\mathrm{pH}(3.42,7.58)$ & B: Lead Concentration $(109.32,400.68)$ & C: Bacterial Concentration $(1.09,4.01)$ & \\
\hline $\mathbf{1}$ & 3.4 & 109 & 1.1 & 50.4 \\
\hline 2 & 5.5 & 255 & 2.5 & 49.0 \\
\hline 3 & 5.5 & 10 & 2.5 & 56.0 \\
\hline 4 & 5.5 & 255 & 2.5 & 50.8 \\
\hline 5 & 2.0 & 255 & 2.5 & 34.7 \\
\hline 6 & 3.4 & 401 & 4.0 & 56.5 \\
\hline 7 & 5.5 & 255 & 0.1 & 48.6 \\
\hline 8 & 5.5 & 255 & 2.5 & 54.0 \\
\hline 9 & 7.6 & 109 & 4.0 & 70.2 \\
\hline 10 & 9.0 & 255 & 2.5 & 60.0 \\
\hline 11 & 5.5 & 255 & 5.0 & 60.3 \\
\hline 12 & 7.6 & 109 & 1.1 & 66.1 \\
\hline 13 & 3.4 & 401 & 1.1 & 50.3 \\
\hline 14 & 5.5 & 500 & 2.5 & 53.2 \\
\hline 15 & 7.6 & 401 & 4.0 & 72.0 \\
\hline 16 & 5.5 & 255 & 2.5 & 53.8 \\
\hline 17 & 5.5 & 255 & 2.5 & 52.5 \\
\hline 18 & 5.5 & 255 & 2.5 & 59.6 \\
\hline
\end{tabular}

Table 4. ANOVA for Response Surface Quadratic Model of R(Lead Removal of L. acidophilus ATCC4356) ${ }^{\mathrm{a}}$

\begin{tabular}{|c|c|c|c|c|c|}
\hline Source & Sum of Squares & df & Mean Square & F Value & P Value \\
\hline Model & 1206 & 9 & 134 & 15.2 & $0.0004^{\mathrm{b}}$ \\
\hline A-pH & 594 & 1 & 594 & 67.4 & $<0.0001^{\mathrm{b}}$ \\
\hline B-Pb concentration & 1.47 & 1 & 1.47 & 0.167 & 0.6935 \\
\hline C-Bacterial Concentration & 110 & 1 & 111 & 12.6 & $0.0075^{\mathrm{b}}$ \\
\hline AB & 173 & 1 & 174 & 19.7 & $0.0022^{\mathrm{b}}$ \\
\hline AC & 171 & 1 & 171 & 19.4 & $0.0023^{\mathrm{b}}$ \\
\hline BC & 193 & 1 & 193 & 21.9 & $0.0016^{\mathrm{b}}$ \\
\hline$A^{2}$ & 53.0 & 1 & 53.0 & 6.02 & $0.0397^{\mathrm{b}}$ \\
\hline $\mathbf{B}^{2}$ & 2.50 & 1 & 2.50 & 0.283 & 0.6090 \\
\hline $\mathrm{C}^{2}$ & 2.06 & 1 & 2.06 & 0.233 & 0.6421 \\
\hline Residual & 70.5 & 8 & 8.81 & & \\
\hline Lack of Fit & 4.57 & 3 & 1.52 & 0.115 & 0.9473 \\
\hline Pure Error & 65.9 & 5 & 13.2 & & \\
\hline Cor Total & 1276 & 17 & & & \\
\hline
\end{tabular}

${ }^{\mathrm{a}}$ Std.Dev. $=2.97$, R-Squared $=0.944$, Mean $=55.4$, Adjusted $\mathrm{R}^{2}=0.882, \mathrm{C} . \mathrm{V} . \%=5.3$, Predicted $\mathrm{R}^{2}=0.869$

${ }^{\mathrm{b}}$ Significant 


\section{Discussion}

The results show that $L$. acidophilus ATCC4356 had the highest (53.9 $\pm 0.01 \%$ ) lead removal efficiency. Therefore, this strain was selected for further investigation. Several studies showed that physical and cultural conditions affect removal capacity $(19,20)$. Optimization helps us to find the condition with the best output for a system $(7,8,17,21)$. Few studies are conducted on the application of bacteria, particularly LAB, using a methodological approach. For example, Kumar and colleagues (25) used the Box-Behnken design matrix with RSM for removing $\mathrm{Cr}$ (VI), Ni (II), and Zn (II) ions with immobilized bacterial strain Bacillus Brevis. They investigated the effect of parameters such as $\mathrm{pH}$, temperature, and initial concentration of metal ions on adsorption, and the maximum removal of $\mathrm{Cr}$ (VI) was observed as $77.24 \%$ at $\mathrm{pH}$ 2.0, temperature $40^{\circ} \mathrm{C}$, and concentration $35 \mathrm{mg} / \mathrm{L}$. Whereas, removal of $\mathrm{Ni}$ (II) ions was $75.2 \%$ at $\mathrm{pH} 6.0$, temperature $40^{\circ} \mathrm{C}$, and concentration $35 \mathrm{mg} / \mathrm{L}$ and $71.6 \%$ of $\mathrm{Zn}$ (II) ions at $\mathrm{pH} 4.0$, temperature $32.5^{\circ} \mathrm{C}$, and concentration $35 \mathrm{mg} / \mathrm{L}$, respectively.

Zhai and colleagues (5) examined cadmium removal from rice using the Box-Behnken model with a combined RSM approach by L. plantarum. They investigated three effective factors for cadmium removal (i.e., temperatures, fermentation durations, and inoculation amounts of $L$. plantarum). In total, they performed 17 experiments using a quadratic model. Using this model, they calculated the regression equation coefficients, and the data were fitted to a second-order polynomial equation. Sahu and colleagues (26) evaluated and optimized $\mathrm{Cr}$ ions adsorption on activated carbon experimental conditions using RSM. They employed a full factorial CCD, and ANOVA was used to analyze the data. They estimated a high coefficient $\left(\mathrm{R}^{2}\right.$ $=0.92$ ) and according to optimized process parameters, $\mathrm{Cr}(\mathrm{VI})$ removal percentage was higher than $89 \%$. Ince and colleagues examined the removal of $\mathrm{Pb}$ (II) using clay in a batch experimental system. The Box-Behnken experimental design methodology and RSM were used to investigate various effective parameters. Based on their results, a $\mathrm{pH}$ of 5, contact time of 31 minutes, $75 \mathrm{mg}$ for adsorbent dosage, and $100 \mathrm{rpm}$ for agitation speed were optimal conditions used for $\mathrm{Pb}$ (II) removal (27). In another study, Ince and Kaplan Ince examined the removal of $\mathrm{Cr}$ from industrial wastewater using RSM combined with CCD. They reported that the CCD method was identified to yield a maximum $\mathrm{Cr}$ ion removal of $99 \%$ at $\mathrm{pH}$ of 5.0, contact time 23.0 minutes, the adsorbent dosage of $69.4 \mathrm{mg}$, and agitation speed of $135 \mathrm{rpm}$ (28).

In the present study, biomass concentration, $\mathrm{pH}$, and concentration of metals were left to be optimized after the Plackett-Burman design. According to the results, the $\mathrm{pH}$ was the most effective variable for studied strains. In an- other study that is conducted in the same removal condition ( $\mathrm{pH}$, metal concentration, bacterial concentration, and contact time) similar results are obtained $(6,12,29)$, but the effectiveness of the factors was not evaluated. A quadratic model obtained from the CCD matched the experimental data $(P$ value $<0.05)$. The results show that increasing the bacterial concentration improves the removal efficiency. This could be attributed to the increase in the amount of the bacteria and, therefore, adsorbing surface, which prepares more active surfaces for adsorbing metal ions. The same result is reported by Sedighi and colleagues, which investigated the lead removal of Lactobacillus bulgaricus (86.2\%) by biomass concentration of 6.58 g. $\mathrm{L}^{-1}$ and initial lead concentration of $36.2 \mathrm{ppm}$. They concluded that the $\mathrm{pH}$ and weight of dried biomass were the key factors influencing the lead ion removal activity (18). That is consistent with the results of the current study.

According to the results, metal ions concentration has little effect on removal activity so that after decreasing the metal and bacterial concentration at a constant $\mathrm{pH}$, the removal efficiency was increased. Besides, in all concentrations of lead, a decrease in $\mathrm{pH}$, and consequently releasation of $\mathrm{H}^{+}$into the solution, was associated with lower removal efficiency. Based on the findings, the removal activity of metals to the bacteria begun at $\mathrm{pH} 2$ in all cases and risen steeply to essentially a maximum percentage within the next $7 \mathrm{pH}$ units up to $\mathrm{pH}$ 9. The results are consistent with the results reported by Sofu and colleagues (17), which reported that removal efficiency enhances with an increase in $\mathrm{pH}$ from 2 to 6.78 . They also reported that the lead removal efficiency increased from 4.86 to $79.3 \%$ with an increase in adsorbent dosage from 2 to 8 g. $\mathrm{L}^{-1}$, which is in line with the findings of the current study.

\subsection{Conclusions}

To investigate the effects of three selected adsorption variables (namely $\mathrm{pH}$, bacterial, and metal concentration) on the removal of lead the CCD was used. A quadratic model was developed to correlate the variables to the response. Through the analysis of response surfaces, $\mathrm{pH}$ and bacterial concentration were found to have significant effects on removal activity, whereas $\mathrm{pH}$ was the most significant factor (P value $<0.0001$ ). The experimental removal efficiencies at the optimum condition for lead by $L$. acidophilus ATCC4356 (73.9\%) were compatible with predicted values. It is concluded that these two lactobacilli strains can be effectively used for heavy metal adsorption and have an important potential for lead adsorption. However, the potential applicability of these two strain-based bioadsorbent could be further examined on a large-scale. 


\section{Footnotes}

Authors' Contribution: Study concept and design: L. G., and R. K.; analysis and interpretation of data: L. G., and R. K.; drafting of the manuscript: L. G.; critical revision of the manuscript for important intellectual content: L. G., R. K., and GH. J.; statistical analysis: L. G.; Study supervision: R. K., and GH. J.

Conflict of Interests: The authors declare that there is no conflict of interests regarding the publication of this paper.

Funding/Support: No grants were involved in supporting this work.

\section{References}

1. Tchounwou PB, Yedjou CG, Patlolla AK, Sutton DJ. Heavy metal toxicity and the environment. Molecular, clinical and environmental toxicology. Springer; 2012. p. 133-64.

2. Mahalik K, Sahu JN, Patwardhan AV, Meikap BC. Statistical modelling and optimization of hydrolysis of urea to generate ammonia for flue gas conditioning. J Hazard Mater. 2010;182(1-3):603-10.

3. Järup L, Berglund M, Elinder CG, Nordberg G, Vanter M. Health effects of cadmium exposure-a review of the literature and a risk estimate. Scand J Work Environ Health. 1998:1-51.

4. Elazazy MS. Determination of midodrine hydrochloride via Hantzsch condensation reaction: a factorial design based spectrophotometric approach. RSC Advances. 2015;5(60):48474-83.

5. Zhai Q, Guo Y, Tang X, Tian F, Zhao J, Zhang H, et al. Removal of cadmium from rice by Lactobacillus plantarum fermentation. Food Control. 2019;96:357-64.

6. Kirillova AV, Danilushkina AA, Irisov DS, Bruslik NL, Fakhrullin RF, Zakharov YA, et al. Assessment of resistance and bioremediation ability of Lactobacillus strains to lead and cadmium. Int J Microbiol. 2017;2017:1-7.

7. Yolmeh M, Jafari SM. Applications of response surface methodology in the food industry processes. Food Bioprocess Technol. 2017;10(3):41333.

8. Yang J, Li Y, Zhang L, Fan M, Wei X. Response surface design for accumulation of selenium by different lactic acid bacteria. 3 Biotech. 2017;7(1):52.

9. Baș D, Boyacı IH. Modeling and optimization I: Usability of response surface methodology. J Food Eng. 2007;78(3):836-45.

10. Bezerra MA, Santelli RE, Oliveira EP, Villar LS, Escaleira LA. Response surface methodology (RSM) as a tool for optimization in analytical chemistry. Talanta. 2008;76(5):965-77.

11. Stanbury PF, Whitaker A, Hall SJ. Principles of fermentation technology. 3rd ed. Elsevier; 2016.

12. Halttunen T, Salminen S, Tahvonen R. Rapid removal of lead and cadmium from water by specific lactic acid bacteria. Int J Food Microbiol. 2007;114(1):30-5.

13. Halttunen T, Kankaanpaa P, Tahvonen R, Salminen S, Ouwehand AC. Cadmium removal by lactic acid bacteria. Biosci Microflora. 2003;22(3):93-7.
14. Ibrahim F, Halttunen T, Tahvonen R, Salminen S. Probiotic bacteria as potential detoxification tools: assessing their heavy metal binding isotherms. Can J Microbiol. 2006;52(9):877-85.

15. Bisanz JE, Enos MK, Mwanga JR, Changalucha J, Burton JP, Gloor GB, et al. Randomized open-label pilot study of the influence of probiotics and the gut microbiome on toxic metal levels in Tanzanian pregnant women and school children. MBio. 2014;5(5):e01580-14

16. Bhakta JN, Ohnishi K, Munekage Y, Iwasaki K, Wei MQ. Characterization of lactic acid bacteria-based probiotics as potential heavy metal sorbents. J Appl Microbiol. 2012;112(6):1193-206.

17. Sofu A, Sayilgan E, Guney G. Experimental design for removal of Fe(II) and $\mathrm{Zn}$ (II) ions by different lactic acid bacteria biomasses. Int JEnviron Res. 2015;9(1):93-100.

18. Sedighi M, Ghasemi M, Hassan SH, Daud WRW, Ismail M, Abdallah E. Process optimization of batch biosorption of lead using Lactobacillius bulgaricus in an aqueous phase system using response surface methodology. World J Microbiol Biotechnol. 2012;28(5):2047-55.

19. Bayraktar E. Response surface optimization of the separation of dltryptophan using an emulsion liquid membrane. Process Biochem. 2001;37(2):169-75. doi: 10.1016/S0032-9592(01)00192-3.

20. Can MY, Kaya Y, Algur O. Response surface optimization of the removal of nickel from aqueous solution by cone biomass of Pinus sylvestris. Bioresour Technol. 2006;97(14):1761-5. doi: 10.1016/j.biortech.2005.07.017.

21. Kiran B, Kaushik A, Kaushik CP. Response surface methodological approach for optimizing removal of $\mathrm{Cr}(\mathrm{VI})$ from aqueous solution using immobilized cyanobacterium. Chem Eng J. 2007;126(2-3):147-53. doi:10.1016/j.cej.2006.09.002.

22. Ince M, Ince OK. Heavy Metal Removal Techniques Using Response Surface Methodology: Water/Wastewater Treatment. Toxicity of Nanomaterials. Intechopen; 2019.

23. Myers RH, Montgomery DC, Anderson-Cook CM. Response surface methodology: process and product optimization using designed experiments. John Wiley \& Sons; 2016.

24. Kannan N, Rengasamy G. Comparison of cadmium ion adsorption on various activated carbons. Water Air Soil Pollut. 2005;163(1-4):185-201.

25. Kumar R, Singh R, Kumar N, Bishnoi K, Bishnoi NR. Response surface methodology approach for optimization of biosorption process for removal of $\mathrm{Cr}$ (VI), Ni (II) and Zn (II) ions by immobilized bacterial biomass sp. Bacillus brevis. Chemical Engineering Journal. 2009;146(3):401-7.

26. Sahu JN, Acharya J, Meikap BC. Response surface modeling and optimization of chromium (VI) removal from aqueous solution using Tamarind wood activated carbon in batch process. Journal of hazardous materials. 2009;172(2-3):818-25.

27. Ince $\mathrm{M}$, Kaplan Ince $\mathrm{O}$, Onal A. Response surface Modeling for $\mathrm{Pb}$ (II) removal from alcoholic beverages using natural clay: Process optimization with box-Behnken experimental design and determination by Electrothermal AAS. Atomic Spectroscopy. 2018;39(6):242-50.

28. Ince M, Kaplan Ince O. Application of response surface methodological approach to optimize removal of $\mathrm{Cr}$ ions from industrial wastewater. Atomic Spectroscopy. 2019;40(3):91-7.

29. Halttunen T, Collado MC, El-Nezami H, Meriluoto J, Salminen S. Combining strains of lactic acid bacteria may reduce their toxin and heavy metal removal efficiency from aqueous solution. Lett Appl Microbiol. 2008;46(2):160-5. 